\title{
RECUPERAÇÃO ESTÉTICA DE DENTES COM HIPOPLASIA DO ESMALTE - RELATO DE CASO
}

Adrieli BUREY, Fábio Martins SALOMÃO, Glaucia TAZIMA, Márcio Grama HOEPPNER

A hipoplasia do esmalte dental, caracterizada pela má formação da matriz orgânica do tecido é diagnosticada clinicamente como área de irregularidade superficial e/ou alteração de cor, localizada e/ou difusa. A conduta clínica para a resolutividade do problema estético em dentes hipoplásicos depende do grau de severidade da alteração diagnosticada. O objetivo deste trabalho é apresentar o tratamento restaurador realizado pósclareamento dental externo, com o propósito de melhor a estética de dentes com áreas hipoplásicas. O tratamento foi planejado após diagnóstico da extensão das manchas com auxilio de um aparelho fotopolimerizador de lâmpada halógena. Diante da imagem obtida, a remoção do esmalte alterado se fez com ponta diamantada esférica (1013, KG Sorensen), em alta rotação. $\mathrm{Na}$ seqüência, condicionamento do esmalte dental com ácido fosfórico a $37 \%$, por 30 segundos, remoção do agente condicionador e secagem do campo operatório com jato de ar. Em seguida, aplicação e fotopolimerização do sistema adesivo (Adper Easy One, 3M ESPE). Para a restauração foram utilizadas resinas compostas Filtek Z350 XT (3M ESPE), na técnica estratificada (múltiplas camadas), em diferentes graus de opacidade. Diante do resultado obtido, pelo tempo de trabalho consumido e custos operacionais, concluímos o quão satisfatório se mostrou o tratamento realizado.

Palavras-chave: Hipoplasia do Esmalte Dentário; Restauração Dentária Permanente; Estética e Clareamento Dental. 